\title{
Trust ecology and the resilience of natural resource management institutions
} Marc J. Stern $^{1,2}$ and Timothy D. Baird ${ }^{2,3}$

\begin{abstract}
The resilience of natural resource management (NRM) institutions are largely contingent on the capacities of the people and organizations within those institutions to learn, innovate, and adapt, both individually and collectively. These capacities may be powerfully constrained or catalyzed by the nature of the relationships between the various entities involved. Trust, in particular, has been identified repeatedly as a key component of institutional relationships that supports adaptive governance and successful NRM outcomes. We apply an ecological lens to a pre-existing framework to examine how different types of trust may interact to drive institutional resilience in NRM contexts. We present the broad contours of what we term "trust ecology," describing a conceptual framework in which higher degrees of diversity of trust, as conceptualized through richness and evenness of four types of trust (dispositional, rational, affinitive, and systems based), enhance both the efficacy and resilience of NRM institutions. We describe the usefulness and some limitations of this framework based on several case studies from our own research and discuss the framework's implications for both future research and designing more resilient governance arrangements.
\end{abstract}

Key Words: adaptive governance; functional redundancy; institutional resilience; natural resource management; trust

\section{INTRODUCTION}

In the past decade, trust between stakeholders has been identified repeatedly as a key factor driving natural resource management (NRM) outcomes (Cvetkovich and Winter 2003, Davenport et al. 2007, Vaske et al. 2007, Stern 2008a,b). Trust serves as a key enabler of adaptive governance, which describes collaborative decision-making systems in which effective adaptive ecosystem management can take place (Chaffin et al. 2014). Recently, Stern and Coleman (2015) presented a framework that distinguishes between different types of trust and describes how types of trust may interact to affect NRM outcomes. We posit that these outcomes are, in part, functions of the types and degrees of trust that connect the many actors, groups, and stakeholders within NRM institutions. Here, we build on Stern and Coleman's (2015) framework to explore how "trust diversity" influences the resilience of NRM institutions. To do so, we present and describe a broadly conceived "trust ecology," which focuses on the interactions between trust types and functions within institutional settings.

To organize our discussion, we proceed through five steps. Specifically, we: (1) define institutional resilience in the context of NRM, (2) review the key components of Stern and Coleman's (2015) trust framework, (3) present NRM institutions as "trust ecosystems" and describe how trust diversity supports institutional resilience, (4) provide examples from empirical research and management literature to illustrate the applicability of our proposed framework, and (5) identify the practical and theoretical implications of trust ecology as we have conceived it.

\section{INSTITUTIONAL RESILIENCE}

Institutions and their roles in managing resources are diverse. We adopt a sociological definition of institution as a collective solution to a societal problem or challenge (Machlis et al. 1997). NRM institutions focus on the challenge of effectively managing natural resources. NRM institutions may address multiple goals and serve multiple functions under this general definition (e.g., sustainable yield, provision of ecosystem services, recreation, public health, species conservation). Similarly, NRM institutions may also occur at multiple, often nested, scales. For example, the institution of forest management in the Pacific Northwest, which may include multiple stakeholders working in concert (not necessarily together) to manage forests, exists within the broader institution of NRM in the United States. Finally, NRM institutions may take multiple forms. They tend to be conglomerations of government policies and agencies, nongovernmental organizations (NGOs), various special interest groups and industries, local people situated nearest the resources in question, and other concerned citizens who decide to become involved. What makes each an institution is that there are people all working simultaneously to influence NRM.

Here, we propose a general theory of institutional resilience that we believe is broadly applicable to our encompassing definition of NRM institutions, including such forms as protected areas management, urban and regional planning, community-based conservation, and other modes of collaborative governance.

We consider resilience in terms of the general function(s) performed by these institutions, not their specific forms. Given the wide variety of institutional forms, we embrace the perspective that resilient institutions are able to adapt to shocks in ways that preserve their general functions, even as their forms may change. Resilient institutions draw on diverse knowledge, skills, abilities, viewpoints, and relationships to learn, adapt, innovate, and transform in the face of disturbance. These assets collectively constitute their adaptive capacity (Folke et al. 2005). While resilient institutions have the adaptive capacity to preserve (or regain) function in the wake of shocks, important distinctions exist between general and specific functions. Specific functions of an institution (e.g., sustainable tree harvest, rule enforcement, or payment for ecosystem services) may change to ensure the continuance of the more general function (e.g., contextappropriate NRM that addresses societal priorities). To sustain

${ }^{1}$ Department of Forest Resources and Environmental Conservation, Virginia Tech, ${ }^{2}$ Center for Leadership in Global Sustainability, ${ }^{3}$ Department of Geography, Virginia Tech 
this general function, institutions' specific functions (e.g., forms, strategies, goals) may transform when challenges arise (Herrfahrdt-Pähle and Pahl-Wostl 2012). Correspondingly, our approach to institutional resilience focuses on the maintenance of institutions' general functions rather than their form or structure.

An important determinant of an institution's adaptive capacity is its ability to learn and make intentional adjustments to shape change (Folke et al. 2005, Nelson et al. 2007). Scholars of adaptive learning distinguish between single-loop and double- or tripleloop learning (Herrfahrdt-Pähle and Pahl-Wostl 2012, Peterson et al. 2014). Single-loop learning refers to learning that takes place within the existing framework of norms and values and generally does not question underlying assumptions. Researchers have associated this form of learning with what has become known as a "rigidity trap," which describes failure to adapt sufficiently to address challenges (Butler and Goldstein 2010). Alternatively, multiple-loop learning includes the review of assumptions underlying a particular approach to a problem and can also include the questioning of prevalent mental models, values, and norms. These forms of learning can lead to more meaningful adaptations (or transformations) in which institutions may not only alter their strategies but also reconsider their short- and longterm goals and objectives. Therefore, multiple-loop learning may directly enhance institutional resilience by generating a wider array of alternatives for responding to disturbances.

Multiple-loop learning and other factors that support adaptive capacity may be strongly constrained in institutions where people struggle to work together for lack of trusting relationships. Specifically, distrust between stakeholders can lead to stalemates in planning, lawsuits that hold up management actions, noncompliance with regulations, public protests, and even violence (Cvetkovich and Winter 2003, Vaske et al. 2007, Stern 2008a,b, 2010, Lachapelle and McCool 2012). The inability of groups to trust each other can severely undermine the potential for learning and experimentation, leading to suboptimal outcomes for all parties involved and for natural resources (Stern et al. 2014). Moreover, distrust may lead to the formation and reification of risk averse cultures within and across organizations, further curtailing opportunies for innovation and experimentation necessary for effective adaptive ecosystem management (Stern and Mortimer 2009, Schein 2010, Stern et al. 2014). Alternatively, higher degrees of trust and greater trust diversity within NRM institutions may allow the parties involved to share and examine their assumptions with one another and work together more effectively (Stern and Coleman 2015). Here, we examine how this might happen.

\section{TRUST WITHIN NATURAL RESOURCE MANAGEMENT INSTITUTIONS}

We define trust as an individual's willingess to accept vulnerability in the face of uncertainty (Rousseau et al. 1998, Möllering 2006). Trust is typically based on some form of positive expectation about the potential trustee. In this section, we draw on the framework developed by Stern and Coleman (2015) to describe four distinct types of trust relevant to NRM: dispositional, rational, affinitive, and systems based. Each of these types of trust is distinguishable by the the ways in which positive expectations are developed (Table 1). While each is theoretically distinct, they regularly interact in real-world decision-making situations (Dietz 2011). The following paragraphs describe each type of trust in detail.

Dispositional trust is based on individuals' pre-dispositions to trust or distrust in a given situation. These tendencies are typically based on personal histories, innate personalities, or general hearsay about a particular situation prior to involvement. Dispositional trust sets the baseline from which an individual may develop other types of trust or distrust. In NRM settings, dispositional trust is often on the lower end of the spectrum for many participants because their involvement is typically based on a concern that their desired outcomes may not otherwise be met (Smith et al. 2013).

Rational trust is based on trustors' evaluations about what they believe to be the likely outcomes of potential trustees' likely actions. If trustors' predictions about those outcomes are positive, then rational trust may generally be high. As such, rational trust is typically predicated on past effective and consistent performance by the trustee and his/her/its demonstrated ability to produce a particular outcome. For example, if park rangers have been effective and consistent in prohibiting illegal timber harvest, a person who believes this is a good thing might have positive rational trust for the agency. That same person might rationally distrust the agency if performance had been ineffective. Meanwhile, a person who would prefer to harvest timber illegally might actively distrust the agency for rational reasons in this case as well.

Affinitive trust does not necessarily involve explicit predictions about a particular outcome of a behavior. Rather, it is based on an affinity for the potential trustee. Affinitive trust may come about through feelings of social connectedness, positive shared experiences, perceptions of shared identities, or assumptions of the similarity of salient values (Braithwaite 1998, Cvetkovich and Winter 2003, Stern 2008b). Affinitive trust thus commonly develops through the cultivation of meaningful personal relationships. In formal institutional contexts, these may commonly emerge from social interactions between participants, clear expressions of similar values, or the demonstration of active listening and responsiveness on behalf of potential trustees. The distinsguishing feature between rational and affinitive trust is that rational trust is based on a calculative evaluation of a predicted outcome, whereas affinitive trust is based on an affinity for the trustee.

Systems-based trust involves trust in a system or set of procedures or rules, rather than trust in an individual or organization. In NRM contexts, systems-based trust develops when procedures are viewed as legitimate by all actors. In other words, all participants view the procedures as fair (Tyler 1990). Research in this area suggests that such legitimacy may emerge from multiple sources, including joint procedural development, transparency in decision-making, power sharing, and the equitable distribution of benefits and risks (Suchman 1995, Levi and Stoker 2000, Gezelius 2002, Sunshine and Tyler 2003, Stern 2008b). When procedures are jointly agreed upon as fair, participants can place greater faith in the compliance of others. This can allow for other types of trust to develop more easily. Moreover, trust in the system can reduce the importance of other types of trust. Systems-based trust reduces the vulnerability of individual participants to the 
Table 1. Trust types and their bases, functions, and examples of how they buffer disturbances to other trust types.

\begin{tabular}{|c|c|c|c|c|}
\hline $\begin{array}{l}\text { Trust } \\
\text { type }\end{array}$ & Basis & Primary function & $\begin{array}{l}\text { Common } \\
\text { disturbances }\end{array}$ & Examples of buffering \\
\hline \multicolumn{5}{|c|}{ Dispositional } \\
\hline & $\begin{array}{l}\text { Predispositions of individuals to } \\
\text { trust or distrust; based on } \\
\text { personal histories, general } \\
\text { hearsay, and innate tendencies }\end{array}$ & $\begin{array}{l}\text { Baseline from which } \\
\text { trust and/or distrust } \\
\text { can be built or eroded }\end{array}$ & $\begin{array}{l}\text { Prior histories; } \\
\text { external events }\end{array}$ & $\begin{array}{l}\text { Rational: effective performance can shift negative } \\
\text { dispositions } \\
\text { Affinitive: positive personal relationships can shift negative } \\
\text { dispositions } \\
\text { Systems based: fair and transparent procedures can allow } \\
\text { for initial risk-taking despite negative dispositions }\end{array}$ \\
\hline \multicolumn{5}{|r|}{ te } \\
\hline & $\begin{array}{l}\text { Contingent on evaluations of } \\
\text { likely outcomes of potential } \\
\text { trustees' predicted behavior; } \\
\text { based largely on assessments of } \\
\text { prior performance and cost/ } \\
\text { benefit analysis of likely future } \\
\text { performance }\end{array}$ & $\begin{array}{l}\text { Enables agreement on } \\
\text { actions, information } \\
\text { sharing, learning, and } \\
\text { adaptation }\end{array}$ & $\begin{array}{l}\text { Performance failures; } \\
\text { alternative means for } \\
\text { reaching personal } \\
\text { goals }\end{array}$ & $\begin{array}{l}\text { Affinitive: positive personal relationships can speed } \\
\text { recovery following performance failures and can provide } \\
\text { greater weight to certain alternatives for reaching goals } \\
\text { Systems based: agreed-upon procedures may be in place for } \\
\text { addressing performance failures }\end{array}$ \\
\hline \multicolumn{5}{|l|}{ Affinitive } \\
\hline (3) & $\begin{array}{l}\text { Contingent on perceptions of } \\
\text { shared values or other affinity } \\
\text { with potential trustees; often } \\
\text { developed through positive } \\
\text { direct interactions in which } \\
\text { responsiveness and active } \\
\text { listening have been demonstrated }\end{array}$ & $\begin{array}{l}\text { Enables agreement on } \\
\text { actions, information } \\
\text { sharing and deeper } \\
\text { levels of learning, } \\
\text { adaptation, and } \\
\text { potential } \\
\text { transformation }\end{array}$ & $\begin{array}{l}\text { Turnover of } \\
\text { personnel; competing } \\
\text { relationships; values- } \\
\text { based failure (lapse of } \\
\text { integrity) }\end{array}$ & $\begin{array}{l}\text { Rational: effective performance can keep people involved, } \\
\text { even if personal relationships are not developed effectively } \\
\text { Systems based: fair and transparent procedures can allow } \\
\text { new participants to focus on building relationships, rather } \\
\text { than burning energy understanding or reinventing a } \\
\text { process; procedures may include specific practices for } \\
\text { developing relationships with new participants }\end{array}$ \\
\hline \multicolumn{5}{|c|}{ Systems based } \\
\hline & $\begin{array}{l}\text { Fair and transparent procedures } \\
\text { buffer individuals' degree of risk } \\
\text { in potential trust relationships }\end{array}$ & $\begin{array}{l}\text { Lessens the } \\
\text { importance of other } \\
\text { forms of trust; } \\
\text { individuals can work } \\
\text { together with less } \\
\text { interpersonal trust if } \\
\text { systems-based trust is } \\
\text { high }\end{array}$ & $\begin{array}{l}\text { Changing policies, } \\
\text { leadership, funding, or } \\
\text { goals of an } \\
\text { organization or } \\
\text { system; catastrophic } \\
\text { environmental change }\end{array}$ & $\begin{array}{l}\text { Rational and/or affinitive trust between people or for an } \\
\text { organization can allow groups to move forward and } \\
\text { directly address system changes together through social } \\
\text { and/or organizational learning }\end{array}$ \\
\hline
\end{tabular}

actions of others, as long as they can assume that others will follow the agreed-upon rules.

Over-reliance on systems-based trust, however, can have negative effects on other types of trust. For example, a fully coercive system may enable participants to predict the actions of others but may preclude the need for other types of trust to develop entirely. In other words, systems-based trust or distrust may overpower or crowd out the development of other types of trust (Puranam and Vanneste 2009).

As these descriptions indicate, different trust types can fit different niches within an institution and serve different functions in NRM. For example, different people may place different values on different types of trust, some placing more weight on consistent performance (rational trust), and others on meaningful personal relationships (affinitive trust; Braithwaite 1998). Others may consider the procedures (associated with systems-based trust) involved in decision-making to be more important than the individuals involved (Tyler 1990). As such, different trust types may influence collaboration differently for different people and groups. In each case, the types and degrees of trust that exist between individuals or groups within the institution confer particular functions that ultimately support (or fail to support) the institutional mission.

Each type of trust may exist along two separate spectra: a positive trust spectrum and a distrust spectrum. Each describes the degree (e.g., absent, weak, strong) of positive trust or distrust held by a potential trustor. At one end of each of these spectra lies a general lack of trust. At the other lies either positive trust, which we hereafter refer to as "trust," or distrust. Distrust is quite distinct from a mere lack of trust. Lack of trust refers to situations in which a potential trustor has inadequate information to make a judgment about whether to trust a potential trustee. In contrast, distrust involves an explicit negative expectation about the potential trustee (Lewicki et al. 1998). Rational distrust may arise from prior performance failures. Affinitive distrust may arise from an interpersonal argument or betrayal. Either form of interpersonal trust (or distrust) might disappear in the case of personnel turnover, replaced by a lack of trust in new personnel (as opposed to positive trust or distrust). Positive trust, lack of trust, and distrust each function differently within a NRM institution (Table 2). For example, a general lack of trust may lead to apathy, hesitancy to become involved, or active information seeking. Explicit distrust may more commonly lead to selectively screening information to confirm one's beliefs (e.g., Haidt 2001), disengagement, or active protest or sabotage (Stern 2008b, 2010).

Scale is another important factor that shapes the distribution and function of trust types and degrees in NRM institutions. NRM institutions typically involve multiple types of active and passive participants, including government agencies, NGOs, private ind ustry, and private citizens acting collectively and as individuals. Trust, distrust, or lack of trust for each of these entities can exist 
Table 2. Examples of positive functions (those contributing to effectiveness and resilience) and negative functions (those detracting from effectiveness and resilience) of distrust, lack of trust, and trust.

\begin{tabular}{lcc}
\hline \hline Trust type & Positive function & Negative function \\
\hline Distrust & Motivation to participate; deliberation & Unproductive conflict; withholding information; \\
& sabotage; withdrawal \\
Lack of trust & Apathy; withdrawal \\
Trust & Cotivation to participate; deliberation & Apathy; complacency \\
& capital & \\
\hline
\end{tabular}

at multiple scales. For example, one might trust an individual who represents a larger organization or one might trust (or distrust) the organization. Trust can also conflict across different scales. For example, one might trust multiple individuals and/or organizations within a NRM institution, but not trust the overall institution to accomplish its goals for any number of reasons (or an individual within an organization, but not the organization). Each form of trust may be apparent at each level. For example, one might rationally trust an organization based on its prior performance or affinitively trust it based on how its agents represent themselves to the public and/or how the organization has marketed itself more broadly. Given the complex ways in which trust and distrust can support or undermine connections between parties within and across institutional scales, trust diversity may serve as a potentially important source of institutional resilience.

\section{TRUST ECOLOGY: LINKING TRUST DIVERSITY TO INSTITUTIONAL RESILIENCE}

Similar to other types of systems, systems or networks of trust, which undergird multi-party NRM, are highly susceptible to multiple forms of disturbance. Correspondingly, strategies to strengthen institutional capacity to withstand or adapt to disturbances (i.e., resilience) are clear priorities. Given that trust is a major driver of multi-party management outcomes and that different types and degrees of trust serve different functions in different contexts, we propose that institutional resilience for NRM may be strengthened where trust diversity is promoted. In other words, NRM will be more resilient where multiple types of trust exist within the institution and are widely distributed. We explain how diversity confers resilience in this section. We first describe how positive trust diversity supports institutional resilience through functional redundancy. We then discuss caveats to our broad theory, especially thresholds, beyond which more trust can harm NRM.

In an ecosystem, diversity confers resilience through functional redundancy. Where multiple species perform the same function within the system, that function will persist even if one species succumbs to a disturbance. Furthermore, the maintenance of certain functions may allow for the reestablishment of lost components, species, or degraded relationships, a process referred to as buffering (e.g., Mori et al. 2013). For example, birds or other animals may re-scatter seeds following a flood. These processes allow for the basic structure and function of the system to persist in the wake of shocks. We propose that trust may work similarly.

Within an ecosystem, biological diversity is typically described in terms of richness and evenness. Richness refers to the number of different types of species or range of genetic variation in the system, whereas evenness refers to the relative abundance of each type (i.e., species, genes). Taken together, high degrees of biological richness and evenness support numerous functions within the system as well as redundancies of these functions. Each conveys system resilience in the face of disturbance. We argue that trust can operate similarly in NRM institutions.

We present trust richness and trust evenness as components of trust diversity. Trust richness is defined as the number of different types of trust exhibited within a network; trust evenness is defined as the relative abundance of trust types within a network. We confine our consideration here to positive trust, and treat distrust and lack of trust separately. Ultimately, trust diversity, comprising richness and evenness, promotes a variety of institutional functions and the redundancy of those functions. In this way, trust diversity supports institutional resilience through functional redundancy and related synergistic relationships that can buffer the effects of trust losses. We have summarized the basis, primary function, common disturbances, and examples of buffering for each type of trust (Table 1). Examples of buffering describe how different forms of trust can buffer the effects of a potential disturbance, loss, or lack of each type.

We also provide a categorical framework that shows how the components of trust diversity, richness and evenness, combine to promote resilience (Fig. 1). Within this framework, we explicitly refer to trust, rather than lack of trust or distrust, such that trust diversity refers to the richness and evenness of different trust types rather than different degrees of trust. When trust richness and evenness are both low, few trust-related functions are served within the network, and the redundancies of served functions are low (Fig. 1, cell A). In other words, when types of trust are limited and skewed (e.g., toward a particular type) in an institutional network, few trust functions are served, and only a sub-sample of these functions are supported in multiple ways (i.e., redundant). Correspondingly, the institution may be weakly resilient to a narrow range of disturbances or only those of low magnitude. It is unlikely that effective management could withstand many types of disturbance or a constellation of disturbances.

Alternatively, when trust richness and evenness are both high, an institution may be strongly resilient to multiple disturbances. In this case, several trust-related functions are served within the network, and the redundancies of served functions are comparatively high (Fig. 1, cell D). When a disturbance affects one type of trust, other types of trust, or trust relationships, can help to buffer the negative effects of the disturbance. For example, affinitive trust may help to buffer a performance failure by a trusted entity. Rational trust for multiple other entities might do 
the same in the case of a trust violation by only one entity. Similarly, systems-based trust might help to buffer the effects of personnel turnover while interpersonal trust is slowly rebuilt.

Fig. 1. Theoretical relationships between trust evenness, trust richness, and institutional resilience to disturbances.

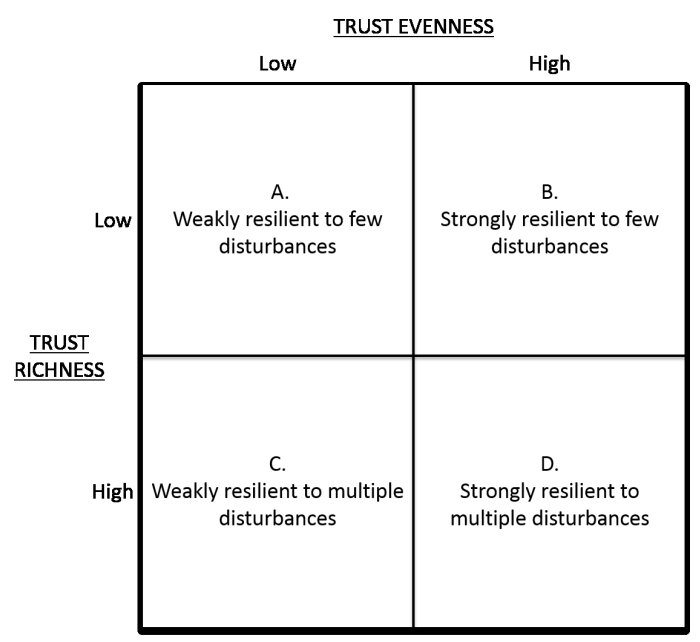

In the cases of low richness and high evenness or high richness and low evenness (Fig. 1, cells B and C), we may expect trade-offs between the magnitude of resilience and the range of disturbances to which the institution may be resilient. For example, when richness is low and evenness is high (Fig. 1, cell B), redundancy may exist, but only for a small number of functions. Correspondingly, the institution may be strongly resilient to only a few types of disturbances and lack resilience to others, regardless of their strength or duration. For example, if only interpersonal (rational and affinitive) types of trust are present, insufficient systems-based trust may be present to buffer the effects of interpersonal trust violations or personnel turnover.

Alternatively, when richness is high and evenness is low (Fig. 1, cell $\mathrm{C}$ ), few redundancies exist. Richness alone may confer low levels of resilience for multiple types of disturbances. In this case, the institution may be able to withstand a wider range of disturbances than institutions with low richness, provided that the strength or duration of these disturbances is low or the disturbances only affect part of the network. One might imagine in this case that trust diversity might be high in one part of a network but not others, or concentrated around a particular entity but not others. Such a system would be particularly susceptible to turnover of a particular person, conflicts between different factions, or other disturbances that affect only a portion of the overall system, because the functions served by rarer types of trust are lost. While the relative merit of cell $\mathrm{B}$ compared to cell $\mathrm{C}$ is subjective and ultimately context specific, cells $\mathrm{B}$ and $\mathrm{C}$ are presented here as objectively preferable to cell $\mathrm{A}$ and less preferable than cell $\mathrm{D}$.

To summarize, we propose that trust diversity supports institutional resilience in general in that richness and evenness may provide functional redundancy as the overall system recovers from disturbances that challenge or diminish pre-existing trust.
However, we note an important caveat regarding degrees of trust, recognizing that systems may reach a saturation point at which the benefits conferred by an increasing abundance of trust diminish.

Beyond a certain threshold, greater degrees of trust may have negative effects on institutional resilience, as well as effectiveness. We refer to this point as the complacency threshold. Near unlimited, or total, trust in other entities or in the overarching institution can demotivate participation because potential participants may assume that their involvement is unnecessary (Nooteboom 2002, Ohno et al. 2010, Smith et al. 2013). Unlimited trust can also reduce the development and integration of diverse ideas and active debate, which may weaken institutional strategies and adaptability (Manz and Neck 1997). Correspondingly, the presence of lack of trust, or even distrust, in small amounts, may serve constructive functions in NRM institutions because they may encourage participation, active deliberation, and the infusion of innovative ideas. However, distrust only serves this function when system-wide positive trust exists to some degree. These notions are supported by theories from organizational psychology, which suggest that a moderate level of disagreement on working teams yields optimal outcomes (Simons and Peterson 2000).

Integrating our arguments regarding the effects of trust diversity and functional redundancy on institutional resilience, generally, at low levels of trust, increases in trust diversity support the establishment of important functions within the institution (Fig. 2). This is represented by the steep slope of the trust function at low levels of trust diversity. Once functions are established, further increases in trust diversity lead to redundancies of existing functions. Resilience begins to develop as increases in trust diversity yield increases in functional redundancy and buffering, until the institution reaches its complacency threshold. Beyond this threshold, further increases in trust diversity may undermine functional redundancy and institutional resilience.

Fig. 2. Theoretical relationships between trust diversity, functional redundancy, and institutional resilience. Uppercase letters correspond roughly to the cells in Fig. 1. Adapted from: Konopka (2009).

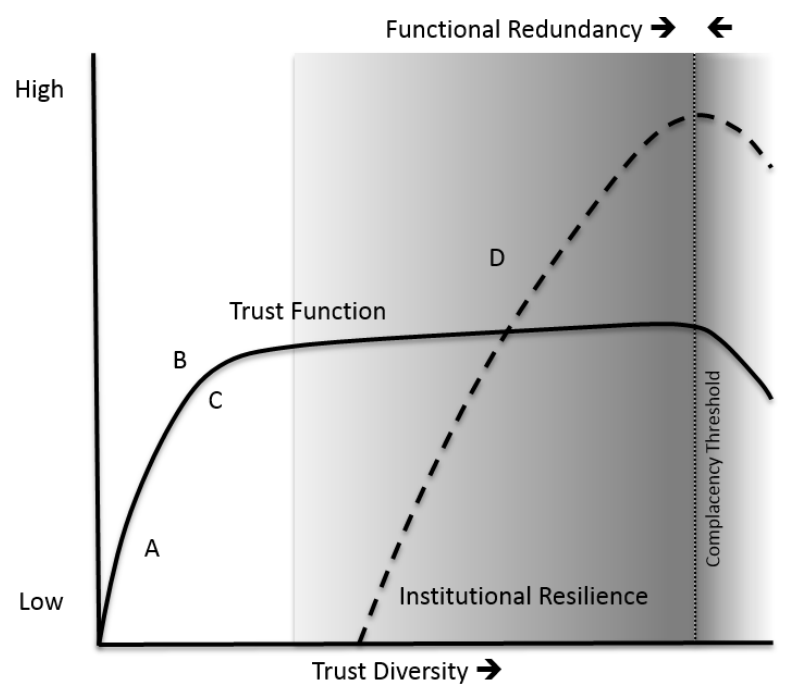


We next offer empirical examples from our own research that serve to illustrate applications of the trust ecology framework in realworld NRM institutions.

\section{EMPIRICAL CASES OF DISTURBANCE AND RESILIENCE IN NATURAL RESOURCE MANAGEMENT INSTITUTIONS}

Disturbances to NRM institutions can emerge from multiple sources, including, but not limited to, catastrophic changes to the resource, relationship breaches of multiple forms, countermovements, process violations, internal disagreements and team conflicts, performance failures, policy changes, and political influences. Other elements can additionally contaminate the effectiveness of NRM institutions, including adherence to old models, groupthink, competing accountabilities, and risk averseness (Esser 1998, Stern et al. 2014). Different disturbances can focus the attentions of actors within NRM institutions on different types of trust. For example, a change in the resource may focus management entities on technical adjustments to management approaches, which in turn would focus institutional actors largely on rational trust assessments of performance and proficiency. Personal disagreements and conflicts can often concentrate institutional actors on both affinitive and systemsbased assessments as interpersonal relationships are strained and actors seek protections from the larger system. We share some examples from our own research to illustrate how trust diversity can enhance the resilience of NRM institutions against disturbances and enhance overall performance.

From 1996 to 2006, Nepal's Maoist insurgency largely dismantled natural resource management in most national parks and protected areas in Nepal. The Annapurna Conservation Area, however, appeared to be somewhat more resilient to the insurgency than other parks, despite being no less threatened (Baral and Stern 2010). Maoist rebels attacked multiple field offices of the governing institution, illegally harvested resources, and personally threatened local conservation agents. The Annapurna Conservation Area is managed by 56 local Conservation Area Management Committees (CAMCs) made up of local people under the umbrella of a broader NGO. Baral and Stern (2011) conducted a study of the differential responses of 30 of these individual committees to the Maoist insurgency, gauging the extent to which each was able to continue to function throughout and immediately following the insurgency. Some proved to be quite resilient, whereas others collapsed. In all cases, systems-based trust was destroyed. No CAMC could continue normal operations because it was too risky to hold normal meetings. In the absence of systems-based trust, affinitive and rational trust provided functional redundancy. Organizational resilience (continued functioning of the committees) was primarily dependent on intracommittee (affinitive and rational) trust between members, the size of members' help networks (people or groups they could call upon for help), and committee members' tenure on the committee. Work was informally delegated to smaller groups; committee members with longerstanding relationships trusted others to carry out functions without the standard procedural majority vote; institutional memory of members with greater tenure allowed them to focus more on adaptive response than on explicitly replacing bureaucratic procedures; larger numbers of trust relationships outside the immediate organization (greater diversity through evenness) also enhanced institutional resilience by filling gaps in activities that locals felt they could not perform (Baral and Stern 2011). In short, the richness (presence of both rational and affinitive trust) and evenness (ample stocks of each type of trust and multiple relationships) allowed some CAMCs to weather the insurgency quite well. Those without these qualities ceased to function and took years to recover when the insurgency ended in 2007 (Baral et al. 2010, Baral and Stern 2011).

In another example, Virgin Islands National Park on the island of St. John, U.S. Virgin Islands, has had a long history of conflict with local residents, dating back to when the land was originally purchased in the 1930s and the park was created in 1956. The park covers two-thirds of the land of the small island and has had dramatic effects on island inhabitants, including cutting off access to inholdings (privately owned land surrounded by park lands), restricting the collection of traditionally used natural resources, and attracting wealthy homeowners from the mainland United States and Europe, which has driven up prices and property taxes for locals. Over the years, public meetings held by the park would provoke shouting and other forms of discontent. Illegal resource extraction was common, and a general ill-will had developed between many local St. Johnians and the national park. Stern $(2008 a, b, 2010)$ conducted research there from 2001 to 2006, examining local responses to the national park and determined through statistical analyses that locals' degree of distrust for park managers to be fair and honest with the local population was the primary driver of their active opposition to the park (manifested primarily in public protest, vandalism, illegal resource extraction, and litigation).

The research further illuminated the importance of trust diversity. Stern systematically asked 115 residents whether there was any time period in which the relationship between the national park and local people had been better than it was at the time of the research. There was a striking consensus; respondents who were alive at the time referred to the late 1970s as a time when parkpeople relationships on St. John felt good. They also suggested that less protest, illegal harvest, and other forms of active opposition took place during this time. Additional interviews with key informants, including long-time locals and park employees, corroborated these claims and proffered a consistent explanation. The superintendent at the time had a rather unique style of management and engagement with local people. He was famous for regularly walking the streets of the main town and chatting with people. He would often host social gatherings at his house. Before making any major decisions that might evoke a response from locals, he would spend a few hours with the locally hired maintenance staff to get their opinions. These staff proved to be critical gatekeepers of information about the park for other local people (Stern 2010). Bureaucratic procedures, rules, and regulations (systems) remained the same; the park continued to operate in an otherwise similar fashion to other time periods. The difference was the development of strong affinitive trust with the park's leader. When the superintendent left his post, however, the state of good will did not last, suggesting that affinitive trust alone is not enough to build resilience into a management institution. Personnel change is common across NRM agencies and conservation organizations. Without attending to rational and systems-based trust, no buffer exists to weather the effects of the turnover of key people. 
The same research methods were applied in Podocarpus National Park, which straddles the spine of the Andes in southern Ecuador. There, a community-based conservation scheme supported $>50$ local organizations by providing small grants intended to engage local communities in alternative livelihoods to direct pressure away from resources within the national park (Stern 2008a,b). There also, distrust in park managers and their partners to be fair and honest with local people was the strongest predictor of local opposition to the park (including illegal harvest, vandalism, public protest, and kidnapping of park guards, among other infractions). Trust, on the other hand, served the opposite function.

In most areas around Podocarpus National Park, local organizations operated on short granting cycles, which would involve calling village-wide meetings, followed by a period in which the organization staff would return to their offices to write grants. This would typically take many months. They would then return to the villages to run a short-term project (e.g., livestock improvement, home garden development). When the funds would run out in 6-12 months, the cycle would begin again. These intermittent cycles fomented meaningful levels of distrust for conservation workers because they failed to develop strong affinitive relationships with local villagers. Moreover, locals began to question the sincerity of these organizations and wondered whether they were keeping money designated for communities for themselves. Some described illegally harvesting within the park purely out of protest rather than any specific need. When new groups would come in, locals were predisposed to distrust them, setting high hurdles for effective programs (Stern 2008b).

In contrast, a few organizations around Podocarpus National Park worked more consistently in particular villages. Not only were local benefits more consistent, but affinitive relationships developed. Some villagers who received no specific benefits from the projects explained that they refrained from hurting the park because of their relationships with the conservation workers they had come to know. Moreover, they could see how these organizations worked, providing a basis for systems-based trust. In these places, where three types of trust existed (rational, affinitive, and systems-based trust), park protection was not only happening, but was also resilient to some forms of external disturbance because locals would defend against others who threatened to harvest park resources (Stern 2006).

The idea that conservation can disrupt livelihoods and undermine systems-based trust has also been explored in the context of Tarangire National Park (TNP) in northern Tanzania (Baird et al. 2009), where interactions between the park and local Maasai communities have been strained and contentious. Disruptions to systems-based trust here have had strong effects on interpersonal forms of trust, threatening the resilience of the pre-existing socialecological system. Here, traditional pastoralist livelihoods and communal forms of land management have played a large role in maintaining natural resources. When TNP was created in 1970 to protect wildlife, local residents were evicted from the area and have since been denied access to natural resources within the park, including water, forage, and fuelwood. In addition to these perceived injustices, communities feel that the park has not lived up to its commitments to share benefits (Sachedina and Nelson 2010, Baird 2014) and that laws to protect communities' authority to determine land use may be circumvented by regional authorities with ties to conservation interests (Davis 2011). Taken together, these experiences and perceptions have shaken communities' confidence in the system-wide laws that protect their authority.

Declining trust in the overarching system has contributed to a shift in the reliance on affinitive and rational types of trust between households in the area (Baird and Leslie 2013). Traditional mechanisms of reciprocity have declined, in particular, informal lending and resource sharing (Baird and Gray 2014). These forms of reciprocal exchange, which have been commonly used within Maasai society to build relationships and manage risk collectively, are rooted in affinitive forms of trust. In the past, loans would be extended to all fellow Maasai, even strangers, to help manage small problems. System-wide stress has influenced an increase in the incidence of unpaid loans. Today, gifts must be exchanged before a loan can be made. Correspondingly, lending now relies more on rational trust than affinitive trust. When asked why these traditional mechanisms were in decline, respondents indicated that "people do not trust each other as they did in the past" (Baird and Gray 2014:22). This situation illustrates how the loss of system-based trust can have strong ripple effects on interpersonal types of trust, particularly when inequitable power arrangements exist across stakeholder groups (in this case, park administrators and local land users). Without a new overarching system that appears legitimate to the stakeholders, the resilience of the social-ecological system remains uncertain.

Examples within the United States also speak to the effects of different types of trust at different scales and between different entities. In the United States, the National Environmental Policy Act (NEPA) dictates a general set of procedural requirements prior to initiating any management action with the potential to significantly affect the environment. These requirements, known collectively as the NEPA process, mandate that federal agencies conduct a process to develop alternative action plans and analyze and disclose the likely effects of each to the public and other stakeholders. NEPA processes often represent the primary means for public input into federal management actions on public lands (Hoover and Stern 2014). Stern and others conducted a series of investigations regarding the drivers of process outcomes across a sample of $>400$ NEPA processes in the U.S. Forest Service (Stern and Predmore 2012, Stern et al. 2013). Their research revealed not only the importance of trust relationships between the agency and external stakeholders, but also trust relationships within the agency. The primary drivers of most outcomes involved relationships between team leaders and their superiors, and the nature of collaboration within interdisciplinary agency teams. These drivers reflected systems-based trust (beliefs about whether the work involved would actually influence the outcome based on the decision-making structure), affinitive trust (personal relationships between members of planning teams), and rational trust (doubts or convictions regarding the quality of each others' work).

We have also observed the effects of trust diversity in current research taking place within collaborative NRM initiatives in the United States. In one collaborative group, interviews with stakeholders revealed different types and degrees of trust and 
distrust within the group. In each case, however, stakeholders have continued to participate because of the presence of a facilitator who has set up what all believe to be a fair system for deliberation and decision-making. Thus, the collaborative network has high richness of trust, but low evenness, with the exception of systemsbased trust. Within this case, some stakeholders have discussed that their continued involvement relies on the presence of the facilitator to organize and mediate the group, stating that they might cease to participate if the system changed because of low levels of trust, and in some cases explicit distrust, for other actors. As such, the institution exhibits a high degree of functionality and effectiveness at the moment. However, one might argue that it exhibits a low degree of resilience if the system itself was threatened by turnover of the facilitator or other changes to the governance structure.

Current trends within collaborative NRM further highlight the importance of trust diversity for institutional effectiveness and resilience (see Stern and Coleman 2015). Common strategies for developing different types of trust include field trips, alternative dispute resolution, and other forms of less traditional engagement with antagonist groups (Beierle and Konisky 2000, Hoover and Stern 2014); setting intermediate, achievable milestones to develop rational trust (Stern and Coleman 2015); and using facilitators or moderators and jointly establishing clear procedures to develop systems-based trust (Rowe and Frewer 2000). Some groups have even adopted minority reports for dissenting entities to voice their opposition publicly to the consensus of the group. In each case, explicit attention to the interaction between each type of trust development could work to enhance institutional resilience.

\section{TRUST REPAIR AND CONGRUENCE: EVIDENCE FOR THE IMPORTANCE OF TRUST DIVERSITY FROM THE MANAGEMENT LITERATURE}

The trust repair literature from the fields of organizational theory and management further support the notion that each of these types of trust need to be addressed together following a major disturbance (Gillespie and Dietz 2009). Following any trust violation, people tend to pay more heed to evidence that would support their own further distrust rather than positive evidence for trust (Slovic 1993, Kim et al. 2004). As such, trust repair efforts must overcome salient negative expectations while simultaneously aiming to restore (or create) positive expectations about future trustworthiness. Gillespie and Dietz (2009) refer to these efforts as distrust regulation and trustworthiness demonstration, respectively.

Distrust regulation involves preventing future transgressions by dealing with the faults that contributed to the original failure. These include systems-based elements such as instituting new regulations, rules, contracts, monitoring processes, and controls (Gillespie and Dietz 2009). However, some researchers have discovered the importance of an affinitive element to distrust regulation as well. If these system controls are implemented voluntarily or are self-induced, they function far better than if they are externally imposed (Nakayachi and Watabe 2005, Dirks et al. 2009).

Trustworthiness demonstration explicitly incorporates both affinitive and rational elements. Suggested efforts at rebuilding affinitive trust include expressions of regret, voluntary penance, acknowledgement of responsibility, and offers of reparations. Efforts at rebuilding rational trust involve setting up opportunities for rapid displays of competence (Gillespie and Dietz 2009).

Management scholars stress the importance of congruence between distrust regulation and trustworthiness demonstration (Gillespie and Dietz 2009), supporting our proposal about the importance of maintaining trust diversity. They also stress that duplicitous impression management is largely ineffective and unsustainable (Kim et al. 2004). In other words, both distrust regulation and trustworthiness demonstration must be addressed directly in a tangible fashion to be resilient to a trust failure.

Further lessons from organizational theory and management suggest that performance (rational or systems-based) failures are quite different from failures that directly erode affinitive trust. Failures in performance may be best addressed through trustworthiness demonstration, whereas distrust regulation may be more important for repairing relationship violations or violations involving integrity breaches (inconsistency between professed values and actions). Individuals tend to weigh positive information more heavily when evaluating performance (rational assessments) and negative information more heavily when evaluating the repair of integrity or other affinitive violations (Snyder and Stukas 1999, Kim et al. 2004). These lessons likely apply as well in the case of NRM institutions, suggesting that the roles of different types of trust may change over time, further supporting our notion of considering trust from an ecological perspective in which moderate to high levels of diversity confer resilience.

\section{CONCLUSIONS}

Taking an ecological perspective, we have described a framework for considering the role of different types of trust in enhancing the resilience of NRM institutions. We have described four types of trust (i.e., dispositional, rational, affinitive, and systems-based) that may serve different functions within the complex networks of people, agencies, and organizations that come together to govern, debate, or otherwise interact in NRM decision-making processes. We argue that greater trust diversity (richness and evenness), up to a certain threshold, can strengthen the adaptive capacity of such institutions by providing functional redundancy. Therefore, explicit attention to the development of actionable types of trust (i.e., rational, affinitive, and systems-based trust) throughout NRM institutions can build more effective and resilient governance of natural resources.

Disturbance is inevitable in NRM, arising from values conflicts, personnel changes, policy changes, and myriad transformations of the natural resources themselves. These disturbances may have positive or negative influences on the effectiveness and resilience of NRM institutions. Trust diversity enhances the adaptive capacity of NRM institutions to respond to disturbances as learning opportunities, enabling constructive conflict, debate, deliberation, and multi-loop learning. Although disturbances that specifically erode trust may be particularly damaging, high trust diversity can buffer negative effects. Consequently, effective NRM may persist in the wake of disturbance that erodes or damages one trust type or relationship but not another because trust diversity and redundancy can buffer the system while the lost or damaged trust type recovers. 
The framework has both theoretical and practical applications for future research and professional practice. In a theoretical sense, we begin to define a trust ecology, explaining how different types of trust may serve different functions within a NRM system and how those functions may serve to buffer each other in the face of disturbance. We encourage others to question our framing and to further explore the avenues of research it opens up. For example, NRM institutions usually contain multiple subcomponents, sub-networks, and patches. The ideas contained within trust ecology provide a foundation for new approaches to social network analysis within these contexts. For example, how do richness and evenness of the different trust types vary across these sub-networks and with what effect? Also, do different types of trust serve different functions in different contexts or for different groups? How much distrust (and in what forms) can be withstood? Do certain amounts or types of distrust have a positive influence on institutional resilience?

For professional practice, trust ecology provides a framework within which to consider and develop strategies for stronger collaboration and adaptive capacity in NRM institutions. Trustbuilding activities may vary widely, including providing clear opportunities to demonstrate consistent and effective performance (i.e., rational trust), providing venues for meaningful social interaction and values exploration (i.e., affinitive trust), and developing transparent procedures collaboratively that reflect the concerns of most or all participants (i.e., systems-based). The trust ecology framework also provides a potentially useful way to conceptualize trust failures as well as delineates clear categories to consider in developing potential answers to the question, "Why isn't this working?" We encourage practitioners to ask themselves which type(s) of trust might be missing from their networks and relationships and to formulate strategies to begin their development.

We recognize that the framework we present is coarse-grained and incomplete. Practical applications of trust ecology will require greater attention to the nuances and complexities that characterize real-world NRM institutions with layered networks and multi-faceted relationships. We further recognize that simple strategies for cultivating an effective trust landscape are unlikely. However, our collective experiences and the literature suggest that trust, in its multiple forms, can play a critical role within diverse NRM institutions, particularly with regard to prospects for promoting adaptive governance (Dietz et al. 2003, Folke et al. 2005, Chaffin et al. 2014). By breaking down the concept into its constituent parts and theorizing on the inter-relationships and practical significance of those parts, we hope to catalyze more indepth consideration of the construct in both research and practice. We encourage researchers and practitioners alike to use, elaborate, expand, subtract, validate, or invalidate the ideas associated with the lens we have provided here.

\section{Responses to this article can be read online at:} http://www.ecologyandsociety.org/issues/responses. $\mathrm{php} / 7248$

\section{Acknowledgments:}

This work was supported in part by the Virginia Agricultural Experiment Station and the Program McIntire Stennis of the National Institute of Food and Agriculture, U.S. Department of Agriculture. The open access publication of this article was sponsored by the Virginia Tech Open Access Subvention Fund.

\section{LITERATURE CITED}

Baird, T. D. 2014. Conservation and unscripted development: proximity to park associated with development and financial diversity. Ecology and Society 19(1): 4. http://dx.doi.org/10.5751/ ES-06184-190104

Baird, T. D., and C. L. Gray. 2014. Livelihood diversification and shifting social networks of exchange: a social network transition? World Development 60:14-30. http://dx.doi.org/10.1016/j. worlddev.2014.02.002

Baird, T. D., and P. W. Leslie. 2013. Conservation as disturbance: upheaval and livelihood diversification near Tarangire National Park, northern Tanzania. Global Environmental Change 23 (5):1131-1141. http://dx.doi.org/10.1016/j.gloenvcha.2013.05.002

Baird, T. D., P. W. Leslie, and J. T. McCabe. 2009. The effect of wildlife conservation on local perceptions of risk and behavioral response. Human Ecology 37(4):463-474. http://dx.doi.org/10.1007/ s10745-009-9264-Z

Baral, N., and M. J. Stern. 2010. Looking back and looking ahead: local empowerment and governance in the Annapurna Conservation Area, Nepal. Environmental Conservation 37 (1):54-63. http://dx.doi.org/10.1017/S0376892909990269

Baral, N., and M. J. Stern. 2011. Capital stocks and organizational resilience in the Annapurna Conservation Area, Nepal. Society and Natural Resources 24(10):1011-1026. http://dx.doi. org/10.1080/08941920.2010.495372

Baral, N., M. J. Stern, and J. T. Heinen. 2010. Growth, collapse, and reorganization of the Annapurna Conservation Area, Nepal: an analysis of institutional resilience. Ecology and Society 15(3): 10. [online] URL: http://www.ecologyandsociety.org/vol15/iss3/ art10/.

Beierle, T. C., and D. M. Konisky. 2000. Values, conflict, and trust in participatory environmental planning. Journal of Policy Analysis and Management 19(4):587-602. http://dx.doi. org/10.1002/1520-6688(200023)19:4<587::AID-PAM4>3.0.CO;2Q

Braithwaite, V. 1998. Communal and exchange trust norms: their value base and relevance to institutional trust. Pages 41-64 in V. Braithwaite and M. Levi, editors. Trust and governance. Russell Sage Foundation, New York, New York, USA.

Butler, W. H., and B. E. Goldstein. 2010. The US Fire Learning Network: springing a rigidity trap through multiscalar collaborative networks. Ecology and Society 15(3): 21. [online] URL: http://www.ecologyandsociety.org/vol15/iss3/art21/.

Chaffin, B. C., H. Gosnell, and B. A. Cosens. 2014. A decade of adaptive governance scholarship: synthesis and future directions. Ecology and Society 19(3): 56. http://dx.doi.org/10.5751/ ES-06824-190356 
Cvetkovich, G., and P. L. Winter. 2003. Trust and social representations of the management of threatened and endangered species. Environment and Behavior 35(2):286-307. http://dx.doi.org/10.1177/0013916502250139

Davenport, M. A., J. E. Leahy, D. H. Anderson, and P. J. Jakes. 2007. Building trust in natural resource management within local communities: a case study of the Midewin National Tallgrass Prairie. Environmental Management 39(3):353-368. http://dx.doi. org/10.1007/s00267-006-0016-1

Davis, A. 2011. 'Ha! What is the benefit of living next to the park? ' Factors limiting in-migration next to Tarangire National Park, Tanzania. Conservation and Society 9(1):25-34. http://dx.doi. org/10.4103/0972-4923.79184

Dietz, G. 2011. Going back to the source: Why do people trust each other? Journal of Trust Research 1(2):215-222. http://dx.doi. org/10.1080/21515581.2011.603514

Dietz, T., E. Ostrom, and P. C. Stern. 2003. The struggle to govern the commons. Science 302:1902-1912. http://dx.doi.org/10.1126/ science. 1091015

Dirks, K. T., R. J. Lewicki, and A. Zaheer. 2009. Reparing relationships within and between organizations: building a conceptual foundation. Academy of Management Review 34 (1):68-84. http://dx.doi.org/10.5465/AMR.2009.35713285

Esser, J. K. 1998. Alive and well after 25 years: a review of groupthink research. Organizational Behavior and Human Decision Processes 73(2-3):116-141. http://dx.doi.org/10.1006/ obhd.1998.2758

Folke, C., T. Hahn, P. Olsson, and J. Norberg. 2005. Adaptive governance of social-ecological systems. Annual Review of Environment and Resources 30:441-473. http://dx.doi.org/10.1146/ annurev.energy.30.050504.144511

Gezelius, S. S. 2002. Do norms count? State regulation and compliance in a Norwegian fishing community. Acta Sociologica 45(4):305-314.

Gillespie, N., and G. Dietz. 2009. Trust repair after an organization-level failure. Academy of Management Review 34 (1):127-145. http://dx.doi.org/10.5465/AMR.2009.35713319

Haidt, J. 2001. The emotional dog and its rational tail: a social institutionist approach to moral judgment. Psychological Review 108(4):814-834. http://dx.doi.org/10.1037/0033-295X.108.4.814

Herrfahrdt-Pähle, E., and C. Pahl-Wostl. 2012. Continuity and change in social-ecological systems: the role of institutional resilience. Ecology and Society 17(2): 8. http://dx.doi.org/10.5751/ ES-04565-170208

Hoover, K., and M. J. Stern. 2014. Constraints to public influence in US Forest Service NEPA processes. Journal of Environmental Planning and Management 57(2):173-189. http://dx.doi. org/10.1080/09640568.2013.849232

Kim, P. H., D. L. Ferrin, C. D. Cooper, and K. T. Dirks. 2004. Removing the shadow of suspicion: the effects of apology versus denial for repairing competence- versus integrity-based trust violations. Journal of Applied Psychology 89(1):104-118. http:// dx.doi.org/10.1037/0021-9010.89.1.104
Konopka, A. 2009. What is microbial community ecology? ISME Journal 3:1223-1230. http://dx.doi.org/10.1038/ismej.2009.88

Lachapelle, P. R., and S. F. McCool. 2012. The role of trust in community wildland fire protection planning. Society and Natural Resources 25(4):321-335. http://dx.doi.org/10.1080/089$\underline{41920.2011 .569855}$

Levi, M., and L. Stoker. 2000. Political trust and trustworthiness. Annual Review of Political Science 3:475-507. http://dx.doi. org/10.1146/annurev.polisci.3.1.475

Lewicki, R. J., E. C. Tomlinson, and N. Gillespie. 2006. Models of interpersonal trust development: theoretical approaches, empirical evidence, and future directions. Journal of Management 32(6):991-1022. http://dx.doi.org/10.1177/0149206306294405

Machlis, G. E., J. E. Force, and W. R. Burch Jr. 1997. The human ecosystem part I: the human ecosystem as an organizing concept in ecosystem management. Society and Natural Resources 10 (4):347-367. http://dx.doi.org/10.1080/08941929709381034

Manz, C. C., and C. P. Neck. 1997. Teamthink: beyond the groupthink syndrome in self-managing work teams. Team Performance Management 3(1):18-31. http://dx.doi. org/10.1108/13527599710171255

Möllering, G. 2006. Trust: reason, routine, reflexivity. Elsevier, Oxford, UK.

Mori, A. S., T. A. Spies, K. Sudmeier-Rieux, and A. Andrade. 2013. Reframing ecosystem management in the era of climate change: issues and knowledge from forests. Biological Conservation 165:115-127. http://dx.doi.org/10.1016/j.biocon.2013.05.020

Nakayachi, K., and M. Watabe. 2005. Restoring trustworthiness after adverse events: the signaling effects of voluntary "Hostage Posting" on trust. Organizational Behavior and Human Decision Processes 97(1):1-17. http://dx.doi.org/10.1016/j.obhdp.2005.02.001

Nelson, D. R., W. N. Adger, and K. Brown. 2007. Adaptation to environmental change: contributions of a resilience framework. Annual Review of Environment and Resources 32:395-419. http:// dx.doi.org/10.1146/annurev.energy.32.051807.090348

Nooteboom, B. 2002. Trust: forms, foundations, functions, failures and figures. Edward Elgar, Cheltenham, UK.

Ohno, T., T. Tanaka, and M. Sakagami. 2010. Does social capital encourage participatory watershed management? An analysis using survey data from the Yodo River watershed. Society and Natural Resources 23(4):303-321. http://dx.doi.org/10.1080/08941920802078224

Peterson, B., J. Montambault, and M. Koopman. 2014. The potential for double-loop learning to enable landscape conservation efforts. Environmental Management 54(4):782-794. http://dx.doi.org/10.1007/s00267-014-0337-4

Puranam, P., and B. S. Vanneste. 2009. Trust and governance: untangling a tangled web. Academy of Management Review 34 (1):11-31. http://dx.doi.org/10.5465/AMR.2009.35713271

Rousseau, D. M., S. B. Sitkin, R. S. Burt, and C. Camerer. 1998. Not so different after all: a cross-discipline view of trust. Academy of Management Review 23(3):393-404. http://dx.doi.org/10.5465/ AMR.1998.926617 
Rowe, G., and L. J. Frewer. 2000. Public participation methods: a framework for evaluation. Science, Technology, and Human Values 25(1):3-29. http://dx.doi.org/10.1177/016224390002500101

Sachedina, H., and F. Nelson. 2010. Protected areas and community incentives in savannah ecosystems: a case study of Tanzania's Maasai Steppe. Oryx 44(3):390-398. http://dx.doi. org/10.1017/S0030605310000499

Schein, E. H. 2010. Organizational culture and leadership. Fourth edition. Jossey-Bass, San Francisco, California, USA.

Simons, T. L., and R. S. Peterson. 2000. Task conflict and relationship conflict in top management teams: the pivotal role of intragroup trust. Journal of Applied Psychology 85(1):102-111. http://dx.doi.org/10.1037/0021-9010.85.1.102

Slovic, P. 1993. Perceived risk, trust, and democracy. Risk Analysis 13(6):675-682. http://dx.doi.org/10.1111/j.1539-6924.1993.tb01329. $\underline{x}$

Smith, J. W., J. E. Leahy, D. H. Anderson, and M. A. Davenport. 2013. Community/agency trust and public involvement in resource planning. Society and Natural Resourecs 26(4):452-471. http://dx.doi.org/10.1080/08941920.2012.678465

Snyder, M., and A. A. Stukas Jr. 1999. Interpersonal processes: the interplay of cognitive, motivational, and behavioral activities in social interaction. Annual Review of Psychology 50:273-303. http://dx.doi.org/10.1146/annurev.psych.50.1.273

Stern, M. J. 2006. Understanding local reactions to national parks: the nature and consequences of local interpretations of park policies, management, and outreach. Dissertation. Yale University, New Haven, Connecticut, USA.

Stern, M. J. 2008a. The power of trust: toward a theory of local opposition to neighboring protected areas. Society and Natural Resources 21(10):859-875. http://dx.doi.org/10.1080/08941920801973763

Stern, M. J. 2008b. Coercion, voluntary compliance and protest: the role of trust and legitimacy in combating local opposition to protected areas. Environmental Conservation 35(3):200-210. http://dx.doi.org/10.1017/S037689290800502X

Stern, M. J. 2010. Payoffs versus process: expanding the paradigm for park/people studies beyond economic rationality. Journal of Sustainable Forestry 29(2-4):174-201. http://dx.doi. org/10.1080/10549810903547809

Stern, M. J., and K. J. Coleman. 2015. The multi-dimensionality of trust: applications in collaborative natural resource management. Society and Natural Resources 28(2):117-132. http://dx.doi.org/10.1080/08941920.2014.945062

Stern, M. J., C. A. Martin, S. A. Predmore, and W. C. Morse. 2014. Risk tradeoffs in adaptive ecosystem management: the case of the U.S. Forest Service. Environmental Management 53 (6):1095-1108. http://dx.doi.org/10.1007/s00267-014-0267-1

Stern, M. J., and M. J. Mortimer. 2009. Exploring NEPA processes across federal land management agencies. General Technical Report PNW-GTR-799. U.S. Department of Agriculture, Forest
Service, Pacific Northwest Research Station, Portland, Oregon, USA. [online] URL: http://static1.squarespace.com/ static/50083efce4b0c6fedbca9def/t/51649502e4b04699617ffb13/1365546242598/nepa_across+agencies_pnw_gtr799.pdf.

Stern, M. J., and S. A. Predmore. 2012. The importance of team functioning to natural resource planning outcomes. Journal of Environmental Management 106:30-39. http://dx.doi.org/10.1016/ j.jenvman.2012.03.049

Stern, M. J., S. A. Predmore, W. C. Morse, and D. N. Seesholtz. 2013. Project risk and appeals in U.S. Forest Service planning. Environmental Impact Assessment Review 42:95-104. http://dx. doi.org/10.1016/j.eiar.2012.11.001

Suchman, M. C. 1995. Managing legitimacy: strategic and institutional approaches. Academy of Management Review 20 (3):571-610. http://dx.doi.org/10.2307/258788

Sunshine, J., and T. R. Tyler. 2003. The role of procedural justice and legitimacy in shaping public support for policing. Law and Society Review 37(3):513-548. http://dx.doi.org/10.1111/1540-5893.3703002

Tyler, T. R. 1990. Why people obey the law. Yale University Press, New Haven, Connecticut, USA.

Vaske, J. J., J. D. Absher, and A. D. Bright. 2007. Salient value similarity, social trust and attitudes toward wildland fire management strategies. Human Ecology Review 14(2):223-232. [online] URL: http://www.humanecologyreview.org/pastissues/ her142/vaskeetal.pdf. 